\title{
A genotype-directed phase I-IV dose-finding study of irinotecan in combination with fluorouracil/leucovorin as first-line treatment in advanced colorectal cancer
}

\author{
E Marcuello',4, D Páez ',4, L Paré2, J Salazar²,3, A Sebio', E del Rio² and M Baiget ${ }^{*, 2}$ \\ 'Medical Oncology, Universitat Autònoma de Barcelona, Pare Claret 167, Barcelona 08025, Spain; ${ }^{2}$ Genetics Departments, Hospital de la Santa \\ Creu i Sant Pau, Universitat Autònoma de Barcelona, Pare Claret 167, Barcelona 08025, Spain; '3-705 CIBERER, Barcelona, Spain
}

BACKGROUND: Infusional fluorouracil/leucovorin (FU/LV) plus irinotecan (FOLFIRI) is one of the standard first-line options for patients with metastatic colorectal cancer (mCRC). Irinotecan is converted into 7-ethyl-I0-hydroxycamptothecin (SN-38) by a carboxylsterase and metabolised through uridine diphosphate glucuronosyl transferase (UGTIAI). The UGTIAI*28 allele has been associated with the risk of developing severe toxicities. The present trial was designed to define the maximum tolerated dose according to UGTIAI genotype. This report focuses on the results of tolerance to different escalated doses of FOLFIRI first-line of chemotherapy.

PATIENTS AND METHODS: Patients undergoing first-line treatment for $\mathrm{mCRC}$ and eligible for treatment with FOLFIRI were classified according to UGTIAI genotype. A total of 94 patients were eligible for dose escalation of irinotecan. The starting dose of biweekly irinotecan was $180 \mathrm{mg} \mathrm{m}^{-2}$ for the *1/*1, $110 \mathrm{mg} \mathrm{m}^{-2}$ for the *1/*28 and $90 \mathrm{mg} \mathrm{m}^{-2}$ for the *28/*28 genotypes.

RESULTS: The dose of irinotecan was escalated to $450 \mathrm{mg} \mathrm{m}^{-2}$ in patients with the *I/*I genotype, to $390 \mathrm{mg} \mathrm{m}^{-2}$ in those with the * | $/ 28$ genotype and to $150 \mathrm{mg} \mathrm{m}^{-2}$ in those with the *28/*28 genotype. Neutropenia and diarrhoea were the most common grade 3 or 4 toxicities.

CONCLUSIONS: Our results demonstrated that the recommended dose of $180 \mathrm{mg} \mathrm{m}^{-2}$ for irinotecan in FOLFIRI is considerably lower than the dose that can be tolerated for patients with the UGTIAI $*|/ *|$ and $* \mid / * 28$ genotypes. The maximum tolerable dose (MTD) in patients with a high-risk UGTIAI *28/*28 genotype is $30 \%$ lower than the standard dose of $180 \mathrm{mg} \mathrm{m}^{-2}$.

British Journal of Cancer (201 I) 105, 53-57. doi:I0.1038/bjc.20 I I.206 www.bjcancer.com

Published online 7 June 2011

(c) 201 I Cancer Research UK

Keywords: irinotecan; colorectal cancer; UGTIAI; pharmacogenetics

Colorectal carcinoma is the third cause of cancer-related mortality in industrialised countries. Although some metastatic disease may benefit from surgical resection, chemotherapy is the prime therapeutic tool in advanced disease, as it aims to palliate symptoms and increase time to disease progression (TTP) as well as overall survival.

In the last 40 years, fluorouracil (FU) has been the most widely used chemotherapeutic agent in the treatment of advanced disease. In the early 1980s, a modulation of FU with folinic acid helped to increase the response rate and lengthen the TTP. Furthermore, the advent of new drugs such as irinotecan and oxaliplatin in different combinations with fluoropyrimidines has improved outcome in many patients (Douillard et al, 2000; Saltz et al, 2000; Köhne et al, 2005; Saunders and Iveson, 2006). This scenario has improved even more with the recent introduction of new biological drugs

\footnotetext{
*Correspondence: Dr M Baiget; E-mail: mbaiget@santpau.cat

${ }^{4}$ These authors contributed equally to this work.

Received 17 February 2011; revised 27 April 201 I; accepted 12 May 20I I; published online 7 June $201 \mathrm{I}$
}

such as bevacizumab or cetuximab in the treatment schemes (Hurwitz et al, 2004; Van Cutsem et al, 2009).

Infusional FU/leucovorin (LV) plus irinotecan (FOLFIRI) is one of the standard first-line options for patients with metastatic colorectal cancer (mCRC). The recommended dose for irinotecan in combination with $\mathrm{FU}$ in first-line chemotherapy is $180 \mathrm{mg} \mathrm{m}^{-2}$ every 2 weeks (Ducreux et al, 1999; Tournigand et al, 2004), and a phase-II trial reported a high response rate using $260 \mathrm{mg} \mathrm{m}^{-2}$ every 2 weeks with a median TTP of 8 to 10 months and median survival of 22 months (Duffour et al, 2002). When doses of irinotecan were increased, the most frequent side effects were myelotoxicity and diarrhoea.

Irinotecan is converted into 7-ethyl-10-hydroxycamptothecin (SN-38) by a carboxylsterase, and finally metabolised through uridine diphosphate glucuronosyl transferase enzyme (UGT), predominantly by UGT1A1 isoenzyme. UGT1A1 is a polymorphic enzyme. The number of TA repeats $(5,6,7$ or 8$)$ in the TATA box of the UGT1A1 promoter region is inversely correlated with the gene transcription efficiency and overall enzyme activity. The presence of seven repeats $\left(\mathrm{TA}_{7}\right)$ results in the variant allele UGT $1 \mathrm{~A} 1{ }^{*} 28$ compared with the normal genotype of six TA repeats $\left(\mathrm{UGT} 1 \mathrm{~A} 1^{\star} 1\right)$. This polymorphism has been related to 
myelosuppression and severe diarrhoeic toxicity in UGT1A1*28/ ${ }^{*} 28$ and UGT1A ${ }^{\star} 1 /{ }^{*} 28$ genotypes (Ando et al, 2000; Innocenti et al, 2004; Marcuello et al, 2004; Rouits et al, 2004; Toffoli et al, 2006; Hoskins et al, 2007; Kim and Innocenti, 2007). Individualising doses according to UGT1A1 genotype has been proposed to optimise treatment efficacy and tolerance. The present trial was designed to define the maximum tolerated dose (MTD) according to UGT1A1 genotype. We report the results of tolerance to different escalated doses of irinotecan plus infusional 5-fluorouracil/leucovorin (FOLFIRI) in first-line chemotherapy.

\section{PATIENTS AND METHODS}

\section{Patients}

A total of 94 patients receiving the FOLFIRI regimen were included in the study. Eligibility criteria included histologically proven mCRC or a locally advanced recurrence after surgery, age $\geqslant 18$ years, an Eastern cooperative oncology group (ECOG) performance status of 0 to 2, life expectancy of more than 3 months and adequate bone marrow function (haemoglobin $\geqslant 10 \mathrm{~g} \mathrm{dl}^{-1}$, neutrophil count $\geqslant 1500 \mu \mathrm{l}^{-1}$ and platelet count $\geqslant 100000 \mu \mathrm{l}^{-1}$ ), renal function (creatinine clearance more than $60 \mathrm{ml} \mathrm{min}^{-1}$ ) and liver function (serum creatinine and bilirubin $<1.5 \times$ the upper limit of normal and AST and ALT $\leqslant 2.5 \times$ the upper limit of normal). The exclusion criteria were ECOG $>2$, apparent jaundice or severe comorbidities. Analysis of the UGT1A1 genotype was mandatory for inclusion in this trial.

Before starting the treatment, complete medical history, physical examination, complete analytical studies including blood counts, liver and renal function, ionogram, lactate dehydrogenase, alkaline phosphatise, CEA determination and chest, abdomen and pelvic computed tomography scan were performed in all patients. Patients were classified according to the European Organisation for Research and Treatment of Cancer (EORTC) clinical model validated by Köhne et al (2002). Follow-up was conducted throughout the treatment period until disease progression or death. Responses and progression were evaluated every 12 weeks using Response Evaluation Criteria in Solid Tumours (RECIST). Time to disease progression was assessed from inclusion until disease progression was evident. Toxicity was assessed at every visit using the National Cancer Institute Common Toxicity Criteria version 3.0. Written informed consent was obtained and the study was approved by the Institutional Ethics Committee and by the Spanish Agency for Medicines and Medical Devices $\left(\mathrm{N}^{\circ}\right.$ EudraCT '2007-006788-65').

\section{Study design and dose escalation}

The primary end-point was assessment of the MTD of irinotecan and dose-limiting toxicity (DLT) at cycle 1 . Secondary end-points included the objective response rate and TTP.

Patients were treated with the FOLFIRI scheme. The dose of irinotecan, administered as a 2 -h intravenous (i.v.) infusion on day 1 , was escalated at different levels according to UGT1A1 genotype. The starting dose of irinotecan was 180 in ${ }^{\star} 1 /{ }^{\star} 1$ patients; 110 in $\star 1 / * 28$ and 90 in $* 28 / * 28$.

Leucovorin was administered as a $200 \mathrm{mg} \mathrm{m}^{-2}$ in $2 \mathrm{~h}$ of i.v. infusion during irinotecan infusion followed by 5 -FU at $400 \mathrm{mg} \mathrm{m}^{-2}$ bolus injection, and 5-FU $600 \mathrm{mg} \mathrm{m}^{-2}$ in $22 \mathrm{~h}$ infusion on days 1 and 2 (Douillard et al, 2000). Treatment was repeated every 14 days, if blood counts were adequate. One cycle of treatment consisted of two courses of chemotherapy in 28 days. A complete analytical study was carried out every 7 days during the first cycle.

Dose-limiting toxicity was defined when haematologic grade 4 toxicity, or non-haematologic grade 3-4 toxicities appeared during cycle 1 and persisted despite supportive measures (including antiemetics or antidiarrhoeal agents). Any kind of toxicity that caused hospitalisation or a delay of more than 2 weeks in the treatment administration was considered a DLT. Three patients were scheduled at each dose level. If no toxicity was detected, three new patients were treated with the following dose level. When one patient presented DLT, three new patients received that dose level, and if only one patient had DLT, the following patients were treated with the higher dose level. If two out of three or two out of six patients experienced DLT, the level below was considered MTD. Patients with DLT continued with a $20 \%$ dose reduction in the following cycles. Colony-stimulating granulocyte factor (FEC-G) was allowed in patients with grade 3-4 neutropenia.

\section{UGT1A1 genotyping assay}

Genomic DNA was extracted from peripheral leukocytes by the salting-out procedure (Miller et al, 1989). The TA index of the UGT1A1 promoter was genotyped by fragment sizing. Polymerase chain reaction was performed in a total volume of $25 \mu$ l containing template DNA (80 $\mathrm{ng} \mu \mathrm{l}^{-1}$ ), according to Monaghan et al (1996). The primers used were a forward primer that was modified by the addition of a $5^{\prime}$ fluorescent-labelled FAM and an unlabelled reverse primer (UGT-FAM_F; 5'-GTCACGTGACACAGTCAAA C-3', UGT_R 5'-TTTGCTCCTGCCAGAGGTT-3'). The PCR product $\left(\mathrm{TA}^{\star} 1,98 \mathrm{bp}\right.$; $\left.\mathrm{TA}^{\star} 28,100 \mathrm{bp}\right)$, the internal size standard and Hi-Di formamide (GeneScan 500, Applied Biosystems, Foster City, CA, USA) were mixed. The samples were then run in the ABI Prism 3100 Genetic Analyzer (Applied Biosystems). Fragment sizes were determined by comparison with the internal standard GeneScan 500 using the local Southern algorithm and analysed by GeneMapper software version 3.5 (Applied Biosystems).

Normal, heterozygous and homozygous sequenced samples were included on every run as a quality control. Genotypes were assigned based on the number of TA repeats in each allele (i.e., $\mathrm{TA}^{*} 1 /{ }^{\star} 1, \mathrm{TA}^{*} 1 / \mathrm{TA}^{*} 28$ and $\left.\mathrm{TA}^{*} 28 / \mathrm{TA}^{*} 28\right)$.

\section{Statistics}

Differences between categorical variables were measured by the $\chi^{2}$-test. The Mann-Whitney test was used for comparisons between responses in UGT1A1 genotype and dose. To ascertain the effect of irinotecan dose and the UGT1A1 genotype on response rate, a logistic regression was used as a multivariate method after adjustment for other relevant clinical variables. Time to disease progression was assessed by the Kaplan-Meier method and log-rank test for comparisons. Results were considered statistically significant when $P$-values were less than 0.05 .

\section{RESULTS}

\section{Patient characteristics}

From July 2005 to December 2010, 94 white mCRC or patients with a locally advanced recurrence after surgery were included. Median age at the time of diagnosis was 63 years old. Their characteristics and UGT1A1 genotypes are shown in Table 1.

\section{Dose escalation, toxicities and DLT}

The dose of irinotecan was escalated from 180 to $450 \mathrm{mg} \mathrm{m}^{-2}$ in ${ }^{\star} 1 /{ }^{\star} 1$ patients; from 110 to $390 \mathrm{mg} \mathrm{m}^{-2}$ in ${ }^{\star} 1 /{ }^{\star} 28$ and from 90 to $150 \mathrm{mg} \mathrm{m}^{-2}$ in ${ }^{\star} 28{ }^{\star} 28$ (Table 2 ).

Table 3 summarises the total number of patients included at each dose level of irinotecan together with the number of cases with DLT. 
In the group with the ${ }^{*} 1{ }^{\star} 1$ genotype after two patients presented DLT (grade 3 diarrhoea at $220 \mathrm{mg} \mathrm{m}^{-2}$ and grade 3 asthenia at $260 \mathrm{mg} \mathrm{m}^{-2}$ ), six additional patients were treated with $260 \mathrm{mg} \mathrm{m}^{-2}$ and no DLT was observed. No patient presented a DLT in the $300 \mathrm{mg} \mathrm{m}^{-2}$ level. In the next level of doses $\left(340 \mathrm{mg} \mathrm{m}^{-2}\right)$, one out of six patients developed a DLT (grade 4 asthenia and grade 3 urinary tract infection plus fever causing hospitalisation).

Table I Patients characteristics

\begin{tabular}{|c|c|c|c|}
\hline & No. of patients & & Percentage \\
\hline \multicolumn{4}{|l|}{ Sex } \\
\hline Male & 57 & & 61 \\
\hline Female & 37 & & 39 \\
\hline Age median, years & & 63 & \\
\hline Range & & $33-80$ & \\
\hline \multicolumn{4}{|l|}{ ECOG } \\
\hline 0.1 & 87 & & 93 \\
\hline 2 & 7 & & 7 \\
\hline \multicolumn{4}{|l|}{ Risk group } \\
\hline Low & 58 & & 62 \\
\hline Intermediate & 26 & & 28 \\
\hline High & 10 & & 10 \\
\hline \multicolumn{4}{|l|}{ Primary tumour } \\
\hline Colon & 60 & & 64 \\
\hline Rectal & 34 & & 36 \\
\hline \multicolumn{4}{|c|}{ No of metastatic sites } \\
\hline I & 63 & & 67 \\
\hline$\geqslant 2$ & 31 & & 33 \\
\hline \multicolumn{4}{|l|}{ Assessable } \\
\hline For safety & & 94 & \\
\hline For efficacy & & 56 & \\
\hline \multicolumn{4}{|l|}{ UGTIA I gene } \\
\hline$* \mid / *{ }^{\circ}$ & 42 & & 45 \\
\hline$* \mid / * 28$ & 38 & & 40 \\
\hline$* 28 / * 28$ & 14 & & 15 \\
\hline
\end{tabular}

Abbreviation: $\mathrm{ECOG}=$ Eastern cooperative oncology group.
One out of six had a DLT (prolonged grade 4 asthenia and grade 3 neutropenia) at $390 \mathrm{mg} \mathrm{m}^{-2}$. One further patient at $390 \mathrm{mg} \mathrm{m}^{-2}$ level treated with only one dose of irinotecan was withdrawn because of a protocol violation. Finally, two out of five patients presented a DLT at $450 \mathrm{mg} \mathrm{m}^{-2}$. One patient presented grade 3 diarrhoea and vomiting plus a secondary grade 4 asthenia causing severe dehydration requiring intravenous fluids and hospitalisation. The other case of DLT at $450 \mathrm{mg} \mathrm{m}^{-2}$ consisted of grade 3 diarrhoea and asthenia. Therefore, the MTD in the group of patients with a ${ }^{\star} 1{ }^{\star} 1$ genotype was $390 \mathrm{mg} \mathrm{m}^{-2}$ (Table 3 ).

In the group with a ${ }^{\star} 1 /{ }^{*} 28$ genotype no DLT was observed in the patients treated with less than $300 \mathrm{mg} \mathrm{m}^{-2}$. One patient presented a grade 4 neutropenia at $300 \mathrm{mg} \mathrm{m}^{-2}$ and one patient presented a grade 3 diarrhoea and asthenia at $340 \mathrm{mg} \mathrm{m}^{-2}$ level with catheterrelated sepsis by Staphylococcus aureus requiring intravenous antibiotics and hospitalisation. This dose was the MTD in the ${ }^{\star} 1 /{ }^{\star} 28$ genotype patients because the two first patients treated with a dose of $390 \mathrm{mg} \mathrm{m}^{-2}$ experienced a DLT (grade 3 asthenia and persistent grade 3 neutropenia, respectively) (Table 3 ).

In the ${ }^{\star} 28 /{ }^{*} 28$ genotype only one of six patients presented a DLT (grade 3 diarrhoea) at $90 \mathrm{mg} \mathrm{m}^{-2}$. No patient presented a DLT at the $130 \mathrm{mg} \mathrm{m}^{-2}$ level. As two of five patients at $150 \mathrm{mg} \mathrm{m}^{-2}$ developed a DLT, the MTD was established at $130 \mathrm{mg} \mathrm{m}^{-2}$. One patient presented grade 4 neutropenia and grade 3 asthenia and the other presented grade 3 asthenia and grade 3 constipation with intestinal subocclusion (Table 3 ).

Among all grade 3-4 toxicities, the most frequent severe haematological toxicity during cycle 1 was grade 3-4 neutropenia

Table 2 Irinotecan dose escalation according to the UGTIAI genotype

\begin{tabular}{|c|c|c|c|}
\hline & $\begin{array}{l}\text { Irinotecan dose } \\
\left(\mathrm{mg} \mathrm{m}^{-2}\right) * 1 / * 1\end{array}$ & $\begin{array}{l}\text { Irinotecan dose } \\
\left(\mathrm{mg} \mathrm{m}^{-2}\right) * 1 / * 28\end{array}$ & $\begin{array}{l}\text { Irinotecan dose } \\
\left(\mathrm{mg} \mathrm{m}^{-2}\right) * 28 / * 28\end{array}$ \\
\hline Level I & 180 & 110 & 90 \\
\hline Level 2 & 220 & 125 & 130 \\
\hline Level 3 & 260 & 150 & 150 \\
\hline Level 4 & 300 & 180 & \\
\hline Level 5 & 340 & 220 & \\
\hline Level 6 & 390 & 260 & \\
\hline Level 7 & 450 & 300 & \\
\hline Level 8 & & 340 & \\
\hline Level 9 & & 390 & \\
\hline
\end{tabular}

Table 3 Dose escalation and DLT of increased Irinotecan doses in patients treated with FOLFIRI in *I/*I, *I/*28 and *28/*28 patients

\begin{tabular}{|c|c|c|c|c|c|c|c|c|c|}
\hline $\begin{array}{l}\text { Irinotecan } \\
\text { Dose } \\
\left(\mathbf{m g ~ m}^{-2}\right)\end{array}$ & $\begin{array}{c}\text { No. of } \\
\text { patients with } \\
* I / * I\end{array}$ & $\begin{array}{c}\text { No. of } \\
\text { patients } \\
\text { with DLT }\end{array}$ & Type of DLT & $\begin{array}{c}\text { No. of } \\
\text { patients with } \\
* 1 / * 28\end{array}$ & $\begin{array}{c}\text { No. of } \\
\text { patients } \\
\text { with DLT }\end{array}$ & Type of DLT & $\begin{array}{c}\text { No. of } \\
\text { patients with } \\
* 28 / * 28\end{array}$ & $\begin{array}{l}\text { No. of } \\
\text { patients } \\
\text { with DLT }\end{array}$ & Type of DLT \\
\hline 90 & - & - & - & - & - & - & 6 & । & Grade 3 diarrhoea \\
\hline 110 & - & - & - & 3 & 0 & - & - & - & - \\
\hline $125-130$ & - & - & - & 3 & 0 & - & 3 & 0 & Grade 3 asthenia \\
\hline 150 & - & - & - & 3 & 0 & - & 5 & 2 & $\begin{array}{c}\text { Grade } 4 \text { neutropenia. } \\
\text { Grade } 3 \text { asthenia and } \\
\text { constipation }\end{array}$ \\
\hline 180 & 3 & 0 & - & $9^{a}$ & 0 & - & - & - & - \\
\hline 220 & 6 & 1 & Grade 3 diarrhoea and nausea & 3 & 0 & - & - & - & - \\
\hline 260 & $12^{\mathrm{a}}$ & 1 & Grade 3 asthenia & 3 & 0 & - & - & - & - \\
\hline 300 & 3 & 0 & & 6 & 1 & Grade 4 neutropenia & - & - & - \\
\hline 340 & 6 & 1 & $\begin{array}{c}\text { Grade } 4 \text { asthenia. Urinary } \\
\text { tract infection }\end{array}$ & 6 & 1 & $\begin{array}{c}\text { Grade } 3 \text { diarrhoea. Sepsis } \\
\text { by Staph aureus }\end{array}$ & - & - & - \\
\hline 390 & 6 & 1 & Grade 4 asthenia & 2 & 2 & $\begin{array}{c}\text { Grade } 3 \text { neutropenia } \\
\text { Grade } 3 \text { asthenia }\end{array}$ & - & - & - \\
\hline 450 & 5 & 2 & $\begin{array}{c}\text { Grade } 3 \text { diarrhoea, vomiting } \\
\text { and grade } 4 \text { asthenia. } \\
\text { Grade } 3 \text { diarrhoea and asthenia }\end{array}$ & - & - & - & - & - & - \\
\hline
\end{tabular}


(25\%). Grade 3-4 asthenia was the most common non-haematological toxicity $(18 \%)$. Others severe toxicities were grade 3 diarrhoea $(10 \%)$, infection without neutropenia (4\%), nausea/ vomiting (4\%) and mucositis (1\%). The different grade 3 to 4 toxicities according to the UGT1A1 genotype (including DLT and non-DLT) are summarised in Table 4.

\section{Effect of irinotecan dose on tumour response and survival}

In all, 56 patients were assessable for tumour response. The overall response rate $(\mathrm{ORR}=$ complete plus partial response) was $46 \%$ $(n=25)$. The ORR was $60 \%$ in patients with ${ }^{\star} 1{ }^{\star} 1$ genotype, $39 \%$ in those with ${ }^{\star} 1{ }^{\star} 28$ genotype and $13 \%$ in ${ }^{*} 28 /{ }^{*} 28(P=0.049)$.

To evaluate the relation between irinotecan dose and response rate, we grouped patients into two cohorts according to the median dose of irinotecan: 27 patients treated with $\geqslant 260 \mathrm{mg} \mathrm{m}^{-2}$ and 29 patients treated with a $<260 \mathrm{mg} \mathrm{m}^{-2}$. A statistically significant relationship between irinotecan dose and response rate was observed ( $U$-test, Mann-Whitney; $P=0.023$ ). In all, $67 \%$ of patients treated with $\geqslant 260 \mathrm{mg} \mathrm{m}^{-2}$ of irinotecan achieved a complete or partial response in comparison with only $24 \%$ of patients treated with $<260 \mathrm{mg} \mathrm{m}^{-2}(P=0.001)$ (Table 5). In the logistic regression analysis only $\mathrm{a} \geqslant 260 \mathrm{mg} \mathrm{m}^{-2}$ irinotecan dose independently predicted the probability of response to FOLFIRI (odds ratio $(\mathrm{OR})=5.71$; CI 95\%: $1.76-18.51, P=0.004$ ). The dose level was also associated with a better response rate in the logistic regression analysis $(P=0.02)$.

Median follow-up time was 13 months (range, 1-57 months). Median TTP was 10 months (range, 8-12 months). There were no differences in TTP according to the genotype $(P=0.58)$. Median TTP was higher in patients treated with $\geqslant 260 \mathrm{mg} \mathrm{m}^{-2}$ of

Table 4 First cycle grade 3/4 toxicities (including DLT and non-DLT)

\begin{tabular}{|c|c|c|c|}
\hline \multirow[b]{2}{*}{ Toxicity } & \multicolumn{3}{|c|}{ Genotype } \\
\hline & $\begin{array}{c}* 1 / * 1 \\
n=41 \\
n(\%)\end{array}$ & $\begin{array}{c}* 1 / * 28 \\
n=38 \\
n(\%)\end{array}$ & $\begin{array}{c}* 28 / * 28 \\
n=14 \\
n(\%)\end{array}$ \\
\hline Diarrhoea & $4(10)$ & $2(5)$ & $3(2 \mid)$ \\
\hline Nausea/vomiting & $2(5)$ & $2(5)$ & $0(-)$ \\
\hline Asthenia & $10(24)$ & $4(\mid 1)$ & $3(21)$ \\
\hline Mucositis/stomatitis & I (2) & $0(-)$ & $0(-)$ \\
\hline Anorexia & $0(-)$ & $0(-)$ & $0(-)$ \\
\hline $\begin{array}{l}\text { Infection without concomitant } \\
\text { grade III-IV neutropenia }\end{array}$ & $2(5)$ & $0(-)$ & I (7) \\
\hline Anaemia & $0(-)$ & $0(-)$ & $0(-)$ \\
\hline Neutropenia & $9(22)$ & $10(26)$ & $4(29)$ \\
\hline Thrombocytopenia & $0(-)$ & $0(-)$ & $0(-)$ \\
\hline Fever with concomitant neutropenia & $0(-)$ & $0(-)$ & $0(-)$ \\
\hline
\end{tabular}

Abbreviation: $\mathrm{DLT}=$ dose-limiting toxicity.

Table 5 Response rate: effect of irinotecan dose and UGTAI genotype

\begin{tabular}{|c|c|c|c|c|c|c|c|c|c|c|}
\hline \multirow[b]{2}{*}{ Response } & \multirow[b]{2}{*}{$n$} & \multicolumn{4}{|c|}{ CR+PR } & \multicolumn{4}{|c|}{ SD+PD } & \multirow[b]{2}{*}{$P$} \\
\hline & & $n$ & Percentage & CR & PR & $n$ & $\%$ & SD & PD & \\
\hline Overall & 56 & 25 & 46 & 4 & 21 & 31 & 54 & 22 & 9 & \\
\hline$*|/ *|$ & 25 & 15 & 60 & 1 & 14 & 10 & 40 & 7 & 3 & 0.049 \\
\hline$* \mid / * 28$ & 23 & 9 & 39 & 3 & 6 & 14 & 61 & 8 & 4 & \\
\hline$* 28 / * 28$ & 8 & I & 13 & - & I & 7 & 87 & 5 & 2 & \\
\hline$\geqslant 260 \mathrm{mg} \mathrm{m}^{-2}$ & 27 & 18 & 67 & 2 & 16 & 9 & 33 & 8 & I & 0.001 \\
\hline$<260 \mathrm{mg} \mathrm{m}^{-2}$ & 29 & 7 & 24 & 2 & 5 & 22 & 76 & 14 & 8 & \\
\hline
\end{tabular}

Abbreviations: $C R=$ complete response; $P D=$ progressive disease; $P R=$ partial response; $\mathrm{SD}=$ stable disease. irinotecan (16 months) than in patients treated with $<260 \mathrm{mg} \mathrm{m}^{-2}$ of irinotecan (7 months) months $(P=0.003)$.

In patients with assessable tumour response, a higher TTP was observed in those who achieved a complete or partial response (11 months) than in those with stable disease (10 months) or progressive disease $(2.7$ months; $P<0.001)$ after FOLFIRI treatment. The Cox regression model included the UGT1A1 genotype, ECOG, sex, age, clinical-risk EORTC classification and primary tumour localisation. The risk-group classification $(P=0.003$; $\mathrm{HR}=1.95$; CI $95 \%: 1.25-3.01)$ and $\mathrm{a} \geqslant 260 \mathrm{mg} \mathrm{m}^{-2}$ irinotecan dose $(P=0.003 ; \mathrm{HR}=2.9$; CI 95\%: $1.43-5.88)$ were independent predictors of TTP after adjustment for the other clinically relevant variables.

\section{DISCUSSION}

This study evaluated the DLT and MTD of irinotecan in the FOLFIRI regimen in first-line chemotherapy in mCRC according to UGT1A1 genotype. In this dose-escalating trial, we establish that the standard dose of $180 \mathrm{mg} \mathrm{m}^{-2}$ for irinotecan is significantly lower than the dose that can be tolerated by patients with a UGT1A $1{ }^{*} 1{ }^{\star} 1$ or ${ }^{\star} 1 /{ }^{*} 28$ genotype. A dose escalation was evaluated for the first time in patients with a high-risk UGT1A1 ${ }^{\star} 28 /{ }^{\star} 28$ genotype, and we demonstrated that the MTD was 30\% lower than the standard dose of $180 \mathrm{mg} \mathrm{m}^{-2}$. Although results of tumour response are exploratory, with this dose $\left(130 \mathrm{mg} \mathrm{m}^{-2}\right)$, irinotecan was poorly effective and a more active chemotherapeutic regimen should be considered for this group of patients.

This dose escalation trial of irinotecan in patients with UGT1A1 ${ }^{*} 1{ }^{\star} 1$ and ${ }^{*} 1{ }^{*} 28$ genotypes led us to establish that 390 and $340 \mathrm{mg} \mathrm{m}^{-2}$, respectively, can be safely administered every 2 weeks (MTD) in mCRC patients undergoing first-line treatment with the FOLFIRI regimen. Though slightly higher, these doses, are very similar to those reported in a recent phase I study of irinotecan administered in the FOLFIRI regimen in Italian patients with mCRC: $370 \mathrm{mg} \mathrm{m}^{-2}$ for patients with UGT1A1 ${ }^{\star} 1{ }^{\star} 1$ genotype, and $310 \mathrm{mg} \mathrm{m}^{-2}$ for those with a ${ }^{\star} 1{ }^{*} 28$ genotype. These authors identified these doses as safe to administer when mCRC patients were stratified according to the UGT1A1 genotype, and patients genetically at risk for toxicity $\left({ }^{\star} 28 /{ }^{\star} 28\right.$ ) were excluded (Toffoli et al, 2010). One limitation of our study compared with this work is that a pharmacokinetics analysis was not carried out to describe the effect of different irinotecan doses on patient's drug exposure.

In Japan, the health authorities have approved a two-weekly dose of $150 \mathrm{mg} \mathrm{m}^{-2}$ for irinotecan monotherapy. A phase I/II study determined the recommended dose of FOLFIRI for patients with mCRC without the UGT1A1 ${ }^{*} 28 /{ }^{*} 28$ genotype. Although the MTD was not reached, the conclusions favoured an increase in the irinotecan dose for patients without the ${ }^{\star} 28$ allele to $180 \mathrm{mg} \mathrm{m}^{-2}$ (Yamashita et al, 2011). In this same population, a phase I study of irinotecan and doxifluridine ( $5^{\prime}$-DFUR) for mCRC patients without UGT1A $1{ }^{\star} 28 / * 28$ genotype concluded that the recommended doses of biweekly irinotecan were $150 \mathrm{mg} \mathrm{m}^{-2}$ for patients with the UGT1A1 ${ }^{\star} 1{ }^{\star} 1$ genotype and $70 \mathrm{mg} \mathrm{m}^{-2}$ for those with the ${ }^{\star} 1 /{ }^{\star} 28$ genotype (Hazama et al, 2010). However, a recent Japanese study concluded that no significant differences in the efficacy or toxicity of FOLFIRI between patients with UGT1A $1^{\star} 1{ }^{*} 1$ genotype and those with UGT1 $11^{\star} 1 /{ }^{\star} 6$ or ${ }^{\star} 1 /{ }^{\star} 28$ genotype, when irinotecan dose is $180 \mathrm{mg} \mathrm{m}^{-2}$ (Sunakawa et al, 2010). This suggest that when UGT1A $1 * 28 / * 28$ genotype is excluded, the dose of irinotecan is more relevant than the genotype.

In Caucasian populations, in Italy and Spain, the recommended doses in the phase I studies carried out to date are higher than those in the Japanese trials. These differences may perhaps be attributed to the ethnic differences in UGT1A1 genotypes and/or differences in the therapeutic regimens used. Other combinations with irinotecan that differ from the standard FOLFIRI regimen, 
include those using biological agents, should be explored before making any conclusions.

Our present results also show that a dose $\geqslant 260 \mathrm{mg} \mathrm{m}^{-2}$ is an independent predictor of a better response and higher TTP in mCRC patients without the risk genotype $\left({ }^{*} 28 /{ }^{*} 28\right)$. We therefore suggest that in future phase II and phase III studies, the initial dose of irinotecan in FOLFIRI regimen should be at least $260 \mathrm{mg} \mathrm{m}^{-2}$ in Caucasian patients who have either the ${ }^{\star} 1 /{ }^{\star} 1$ or ${ }^{\star} 1 /{ }^{\star} 28$ UGT1A1 genotype.

Finally, we suggest that as the MTD in patients with a high-risk UGT1A1 ${ }^{*} 28{ }^{\star} 28$ genotype $\left(130 \mathrm{mg} \mathrm{m}^{-2}\right)$ is ineffective, other more

\section{REFERENCES}

Ando Y, Saka H, Ando M, Sawa T, Muro K, Ueoka H, Yokoyama A, Saitoh S, Shimokata K, Hasegawa Y (2000) Polymorphisms of UDPglucuronosyltransferase gene and irinotecan toxicity: a pharmacogenetic analysis. Cancer Res 60: 6921-6926

Douillard JY, Cunningham D, Roth AD, Navarro M, James RD, Karasek P, Jandik P, Iveson T, Carmichael J, Alakl M, Gruia G, Awad L, Rougier P (2000) Irinotecan combined with fluorouracil compared with fluorouracil alone as first-line treatment for metastatic colorectal cancer: A multicentre randomised trial. Lancet 355: 1041-1047

Ducreux M, Ychou M, Seitz JF, Bonnay M, Bexon A, Armand JP, Mahjoubi M, Méry-Mignard D, Rougier P (1999) Irinotecan combined with bolus fluorouracil, continuous infusion fluorouracil, and high-dose leucovorin every two weeks (LV5FU2 regimen): A clinical dosefinding and pharmacokinetic study in patients with pretreated metastatic colorectal cancer. J Clin Oncol 17: $2901-2908$

Duffour J, Gourgou S, Desseigne F, Debrigode C, Mineur L, Pinguet F, Poujol S, Chalbos P, Bressole F, Ychou M (2002) Multicentre phase II study using increasing doses of irinotecan combined with a simplified LV5FU2 regimen in metastatic colorectal cancer. Cancer Chemother Pharmacol 50: $383-391$

Hazama S, Nagashima A, Kondo H, Yoshida S, Shimizu R, Araki A, Yoshino S, Okayama N, Hinoda Y, Oka M (2010) Phase I study of irinotecan and doxifluridine for metastatic colorectal cancer focusing on the UGT1A1*28 polymorphism. Cancer Sci 101: $722-727$

Hoskins JM, Goldberg RM, Qu P, Ibrahim JG, McLeod HL (2007) UGT1A1 28 genotype and irinotecan-induced neutropenia: dose matters. J Natl Cancer Inst 99: 1290-1295

Hurwitz H, Fehrenbacher L, Novotny W, Cartwright T, Hainsworth J, Heim W, Berlin J, Baron A, Griffing S, Holmgren E, Ferrara N, Fyfe G, Rogers B, Ross R, Kabbinavar F (2004) Bevacizumab plus irinotecan, fluorouracil, and leucovorin for metastatic colorectal cancer. $N$ Engl J Med 350: $2335-2342$

Innocenti F, Undevia SD, Iyer L, Chen PX, Das S, Kocherginsky M, Karrison T, Janisch L, Ramírez J, Rudin CM, Vokes EE, Ratain MJ (2004) Genetic variants in the UDP-glucuronosyltransferase $1 \mathrm{~A} 1$ gene predict the risk of severe neutropenia of irinotecan. J Clin Oncol 22: 1382-1388

Kim TW, Innocenti F (2007) Insights, challenges, and future directions in irinogenetics. Ther Drug Monit 29: 265-270

Köhne CH, Cunningham D, Di CF, Glimelius B, Blijham G, Aranda E, Scheithauer W, Rougier P, Palmer M, Wils J, Baron B, Pignatti F, Schöffski P, Micheel S, Hecker H (2002) Clinical determinants of survival in patients with 5-fluorouracil-based treatment for metastatic colorectal cancer: results of a multivariate analysis of 3825 patients. Ann Oncol 13: 308-317

Köhne $\mathrm{CH}$, van Cutsem E, Wils J, Bokemeyer C, El-Serafi M, Lutz MP, Lorenz M, Reichardt P, Rückle-Lanz H, Frickhofen N, Fuchs R, Mergenthaler HG, Langenbuch T, Vanhoefer U, Rougier P, Voigtmann R, Müller L, Genicot B, Anak O, Nordlinger B (2005) Phase III study of weekly high-dose infusional fluorouracil plus folinic acid with or without irinotecan in patients with metastatic colorectal cancer: European Organisation for Research and Treatment of Cancer Gastrointestinal Group Study 40986. J Clin Oncol 23: 4856-4865 active chemotherapeutic regimen should be considered for these patients.

\section{ACKNOWLEDGEMENTS}

DP is the recipient of a fellowship from the Instituto de Salud Carlos III (CM08/00065). This study was sponsored by Instituto de Salud Carlos III (ECO7/90232 Principal Investigator: Dr E Marcuello). We thank Carolyn Newey for English language editing.

Marcuello E, Altés A, Menoyo A, Del Rio E, Gómez-Pardo M, Baiget M (2004) UGT1A1 gene variations and irinotecan treatment in patients with metastatic colorectal cancer. $\mathrm{Br} J$ Cancer 91: 678-682

Miller SA, Dykes DD, Polesky H (1989) A simple salting out procedure for extracting DNA from human nucleated cells. Nucleic Acids Res 16: 1215

Monaghan G, Ryan M, Seddon R, Hume R, Burchell B (1996) Genetic variation in bilirrubin UDP-glucuronosyltransferase gene promoter and Gilbert's syndrome. Lancet 347: 578-581

Rouits E, Boisdron-Celle M, Dumont A, Guérin O, Morel A, Gamelin E (2004) Relevance of different UGT1A1 polymorphisms in irinotecaninduced toxicity: a molecular and clinical study of 75 patients. Clin Cancer Res 10: $5151-5159$

Saltz LB, Cox JV, Blanke C, Rosen LS, Fehrenbacher L, Moore MJ, Maroun JA, Ackland SP, Locker PK, Pirotta N, Elfring GL, Miller LL (2000) Irinotecan plus fluorouracil and leucovorin for metastatic colorectal cancer. Irinotecan Study Group. N Engl J Med 343: 905 -914

Saunders M, Iveson T (2006) Management of advanced colorectal cancer: state of the art. Br J Cancer 95: 131-138

Sunakawa Y, Ichikawa W, Fujita KI, Nagashima F, Ishida H, Yamashita K, Mizuno K, Miwa K, Kawara K, Akiyama Y, Araki K, Yamamoto W, Miya T, Narabayashi M, Ando Y, Hirose T, Saji S, Sasaki Y (2010) UGT1A1*1/ ${ }^{*} 28$ and ${ }^{*} 1 /{ }^{*} 6$ genotypes have no effects on the efficacy and toxicity of FOLFIRI in Japanese patients with advanced colorectal cancer. Cancer Chemother Pharmacol; doi:10.1007/s00280-010-1485-8

Toffoli G, Cecchin E, Corona G, Russo A, Buonadonna A, D'Andrea M, Pasetto LM, Pessa S, Errante D, De Pangher V, Giusto M, Medici M, Gaion F, Sandri P, Galligioni E, Bonura S, Boccalon M, Biason P, Frustaci $S(2006)$ The role of UGT1A1*28 polymorphism in the pharmacodynamics and pharmacokinetics of irinotecan in patients with metastatic colorectal cancer. J Clin Oncol 24: 3061-3068

Toffoli G, Cecchin E, Gasparini G, D’Andrea M, Azzarello G, Basso U, Mini E, Pessa S, De Mattia E, Lo Re G, Buonadonna A, Nobili S, De Paoli P, Innocenti F (2010) Genotype-driven phase I study of irinotecan administered in combination with fluorouracil/ leucovorin in patients with metastatic colorectal cancer. J Clin Oncol 28: $866-871$

Tournigand C, Andre T, Achille E, Lledo G, Flesh M, Mery-Mignard D, Quinaux E, Couteau C, Buyse M, Ganem G, Landi B, Colin P, Louvet C, de Gramont A (2004) FOLFIRI followed by FOLFOX6 or the reverse sequence in advanced colorectal cancer: A randomized GERCOR study. J Clin Oncol 22: 229-237

Van Cutsem E, Köhne CH, Hitre E, Zaluski J, Chang Chien CR, Makhson A, D’Haens G, Pintér T, Lim R, Bodoky G, Roh JK, Folprecht G, Ruff P, Stroh C, Tejpar S, Schlichting M, Nippgen J, Rougier P (2009) Cetuximab and chemotherapy as initial treatment for metastatic colorectal cancer. $N$ Engl J Med 360: $1408-1417$

Yamashita K, Nagashima F, Fujita KI, Yamamoto W, Endo H, Miya T, Narabayashi M, Kawara K, Akiyama Y, Ando Y, Ando M, Sasaki Y (2011) Phase I/II Study of FOLFIRI in Japanese Patients with Advanced Colorectal Cancer. Jpn J Clin Oncol 41: 204-209 